\title{
The possibilities for using wind energy in AP Vojvodina (North Serbia) - Defining the most favorable areas for the construction of windmill farms: A Review
}

\author{
Tijana Đorđević ${ }^{A}$ \\ Received: November 16, 2015 | Revised: February 9, 2016 | Accepted: March 3, 2016
}

\begin{abstract}
As a conventional non-renewable fossil energy sources have a leading role in energy production, constant price increase and lack of resources are the key problem for the whole world. Fossil fuels are the major polluters of the environment which leads to global issues such as global warming, greenhouse effect, acid rain, etc., therefore the growing need and importance of substitution of non-renewable to renewable energy sources is evident. Wind energy as a renewable source of energy has been recognized as one of the cleanest and economically viable substitution of fossil energy sources. Because of this, most countries of the world started to increase their use of wind energy to generate electricity. The Republic of Serbia, which has a remarkable wind potential, is still in the early stages of development in the field of wind energy. Numerous studies confirm that the territory of Vojvodina has the largest wind energy potencial in Serbia. The main objective of this paper is to extract the areas that are most suitable for the construction of wind farms on the basis of defined criteria and with the help of GIS technology in the territory of Vojvodina.
\end{abstract}

Key words: Renewable energy, wind energy, windmill farms, spatial planning, Vojvodina.

\section{Introduction}

The beginning of the $21^{\text {st }}$ century was marked by increased energy consumption in the world, especially fossil fuels (Baños, et al., 2011; Tükenmez, Demir, 2012). Increased consumption has led to a rise in the prices of oil, gas and other fossil fuels, but also to global concerns for future energy sources and development of mankind (Li, Chen, 2009). Another feature of this period was the continuous increase in the concentration of harmful gases in the atmosphere, mainly $\mathrm{CO}_{2}$, as a result of the use of fossil fuels for energy, despite the accepted agreement on reducing greenhouse gas emissions - the Kyoto Protocol from 1997 (Awerbuch, 2007; Golušin, Munitlak-Ivanovic , 2011). All this has led to a sudden change in the energy sector. The developed countries of the world, especially the Europe- an Union, have turned to development and useof renewable energy sources. In that period, the European Union was using only $6 \%$ of energy from renewable sources (mainly hydropower and biomass), while $79 \%$ came from fossil sources - oil products $41 \%$, gas $22 \%$ and coal $16 \%$. In order to stop this negative trend EU adopted the Directive 2001/77 / EC (Energy Development Strategy of Serbia until 2015, 2005), The aim of this Directive was to increase the share of "green" energy in total energy consumption from $6 \%$ to $12 \%$ by 2010. This decision was crucial for the rapid development of the use of all forms of renewable energy.

It is also important to note the significance of the United nations conference on climate change (COP21) held in December 2015 in Paris. One of the main themes of this conference has been promoting renewable ener-

A University of Belgrade, Faculty of Geography, Spatial planning, Studentski trg 3/3, 11000 Belgrade, Serbia 
gy sources. The main product of the conference was the Paris agreement, a document which will, inter alia, all signatory countries commit to a substantial increase in electricity production from renewable sources.

From all renewable energy sources, wind energy is considered to be the most economical solution for reduction of $\mathrm{CO}_{2}$ emissions (Josimović, Pucar, 2010). Although wind energy has been used for about 4000 years (windmills, sailing etc.), the development of modern wind turbines for electricity production starts in 1973 due to the oil crisis. More than 50,000 wind generators were installed since then and industry of wind generators is certainly one of the fastest growing industries in the world (Michalak, Zimny, 2011). Due to the growing need for renewable energy, both for environmental and economic reasons, the European Wind Energy Association (EWEA) has proved that only with the help of wind power can cover more than one-fifth of the electricity needs in Europe (Tükenmez Demirel, 2012). The relatively modest number of scientific publications and studies (eg Gburčik, et al., 2006; Golušin, et al., 2010; Đurišić, et al., 2007; Lalić, et al., 2010; Dodić, et al., 2010; Josimović, Pucar, 2010; Golušin, Munitlak -Ivanović, 2011; Komarov, et al., 2012; Micić, et al., 2014; Wind Atlas of Vojvodina, 2008; Energy Balance of the Autonomous Province of Vojvodina, 2010; Energy Balance of the Autonomous Province of Vojvodina, 2009; Energy Balance of the Autonomous Province of Vojvodina, 2008; Strategy of Energy Development in the Republic of Serbia by 2015 - for the period 2007- 2012, 2005) indicates that in Serbia, the wind as a resource to generate electricity is not sufficiently explored, although there is great potential for its use.

The main objective of this paper is to extract the areas that are most suitable for the construction of wind farms on the basis of defined criteria and with the help of GIS technology in the territory of Vojvodina.

Within the methodological approach, as a general methodological procedures used are generic and statistical methods, and as special: analysis, synthesis, generalization, historical, cartographic methods, GIS method, cognitive description, method of regionalization and research on the field.

\section{Wind as a renewable energy source and its use to generate electricity}

The conversion of wind energy into electricity is Virsa with the help of wind turbines. The wind turbine converter kinetic energy of the wind by the rotor blades, gear mechanism and generator into electrical energy (BDSP University of Stuttgart, 2007).

The nominal wind speed of about $10 \mathrm{~m} / \mathrm{s}$ is used during the construction of wind turbines in order to achieve the highest efficiency rate. The construction of wind turbines for higher wind speeds (greater than 15 $\mathrm{m} / \mathrm{s}$ ) is technically possible, but due to huge dimensions completely uneconomic. Wind turbine has a minimum and maximum working speed so normally works only in a certain range of wind speed. The range is defined by three characteristic speeds (Gvozdenac, et al., 2013):

- Minimum operating wind speed is the value at which the wind turbines began generating electricity and for modern three spoke wind turbines it is between 2.5 and $3.5 \mathrm{~m} / \mathrm{s}$.

- The nominal operating wind speed is the minimum wind speed at which wind turbines reaches its nominal power. For the less windy locations it is between 10 to $13 \mathrm{~m} / \mathrm{s}$, and for the windy locations it is between 14 and $17 \mathrm{~m} / \mathrm{s}$.

- The maximum wind speed is the speed at which wind turbine stops for safety reasons. This value for modern wind turbine is about $25 \mathrm{~m} / \mathrm{s}$, exceptionally $30 \mathrm{~m} / \mathrm{s}$. When it stops working, the wind turbine is mechanically designed to withstand an extremely high wind speed of about $70 \mathrm{~m} / \mathrm{s}$.

The wind turbine can provide economic electricity production at average annual wind speed of $6 \mathrm{~m} / \mathrm{s}$ (BDSP University of Stuttgart, 2007).

The cost of building wind generators are decreasing from year to year. Today approximate investment value for installed $\mathrm{kW}$ is about 700 to $1,000 \mathrm{eu}-$ ros. The price of the construction of wind turbines in the last 15 years dramatically reduced and that trend continues. Therefore the price of electricity produced by means of wind turbines is constantly reducing due to the reduction in operating cost and increase in the efficiency and reliability of wind turbines themselves. Because there are no fuel cost with wind energy, after the investments in the construction of wind generators, only operating and maintenance costs remain. Investment costs range from 75 to $90 \%$ of total costs. The investment costs include the construction of wind turbines themselves, the cost of construction of access roads and the costs of connecting to the electricity system (BDSP University of Stuttgart, 2007).

It is important to note that the price of electricity produced from wind is constantly decreasing due to lower cost of wind turbines themselves, while the prices of electricity from fossil fuels, even with government subventions, are increasing from year to year.

\section{The possibility of using the wind in AP Vojvodina}

The tradition of using the wind in Serbia existed since $18^{\text {th }}$ century. In the $19^{\text {th }}$ century in Vojvodina there were about 280 windmills. The first one was built in 
Elemir near Zrenjanin in the late $18^{\text {th }}$ century (Tomic, et al., 2004).

Vojvodina as a region with great potential for exploitation of wind energy is characterized by several important facts, such as (Wind Atlas of Vojvodina, 2008):

- A good wind energy resources in some parts of the region;

- Accessibility of the area and the lower cost of construction of wind turbines;

- Low cost of transport for large wind turbines from the European Union (through water traffic - Danube river);

- Small number of days with thunder;

- Many individual consumers of electricity in rural areas as potential users of small wind turbine system;

- Creating a favorable framework for the concept of integrated programs and the adoption of legislation in the field of renewable energy sources.

The basic requirement for planning the construction of wind farms is the existence of technically exploitable wind energy potential. As the two most important characteristics of wind for these needs are speed and density of strength of the wind at certain altitudes (between 50 and $200 \mathrm{~m}$ ). Wind energy potential of a certain area is shown on geographical maps which have wind speed and wind power densi- ty at a specific height above the ground engraved on them. A set of such maps is called Wind Atlas.

Wind parameters are systematically measured in the network of weather stations (GMS) of Hydrometeorological Institute of Serbia. In Vojvodina, the stations are placed in Palić, Sombor, Kikinda, Novi Sad (Rimski Šančevi), Zrenjnin, Sremska Mitrovica, Banatski Karlovac and Vršac.

The results of previous studies (The possibility of using wind energy for electricity generation, 2002) show that the territory of Vojvodina mainly have wind speed of $3.5-4.5 \mathrm{~m} / \mathrm{s}$. In certain places (Frška Gora, Vršački Breg, South Banat) wind speed is from $4.5-6 \mathrm{~m} / \mathrm{s}$, and on Vršackki Breg there are two locations with speeds over $6 \mathrm{~m} / \mathrm{s}$. With modern technologies of wind turbines, which allow profitable operation at lower speeds, we can say that the potential is significant.

Highest values of average annual wind speed has a measuring station in Vršac. The dominant wind in this area is the south-east wind blowing in winter, from December to February in most parts of the Vojvodina. The Wind has the largest force onthe exit of the Đerdap gorge near Golubac, where it often has a speed of $100 \mathrm{~km} / \mathrm{h}$. In the southwestern part of Srem, košava turns to east because of the meridian provision of Fruška gora. The impact of košava can be felt on the whole territory of AP Vojvodina and beyond. Most often it blows two to three days, but once it was blowing-

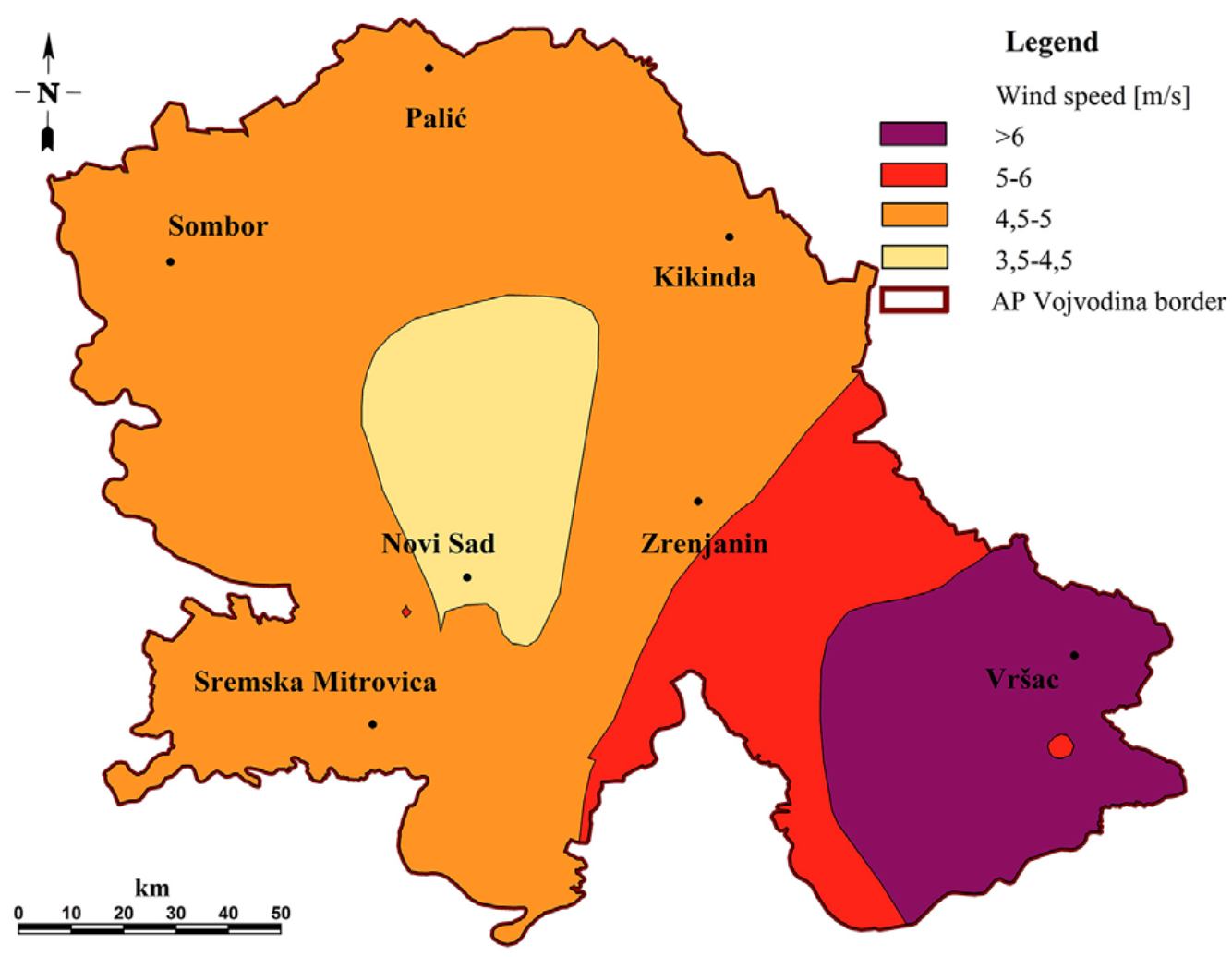

Figure 1. Average annual wind speed at $100 \mathrm{~m}$ above the ground $(\mathrm{m} / \mathrm{s})$ (Wind Atlas of Vojvodina, 2008) 


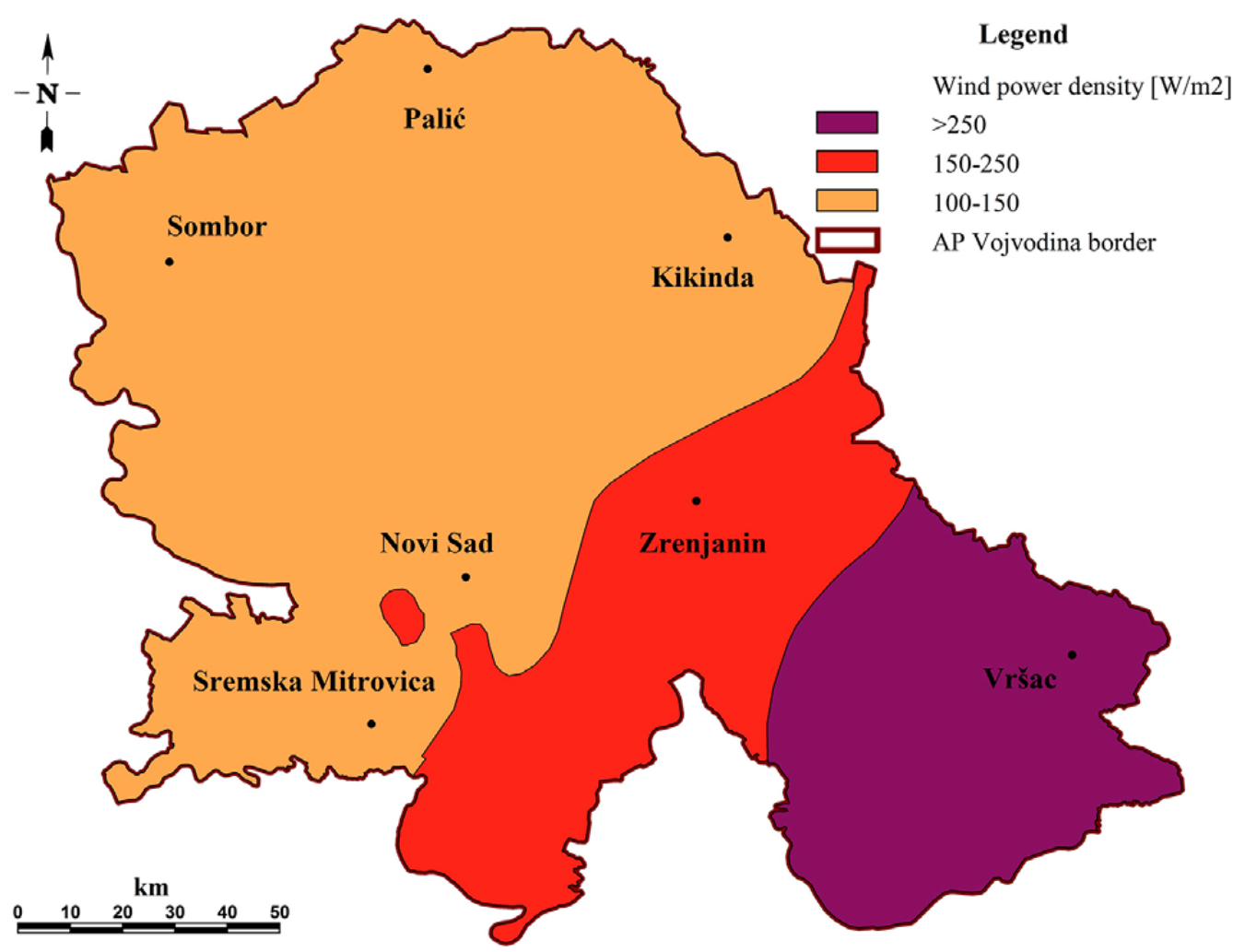

Figure 2. The power density of the wind at 100m above ground (Wind Atlas of Vojvodina, 2008)

for a month without interruption (Dukić, 1981). It's a cold and strong wind, which has great energy potential and it's most important wind for energy production in Banat (Wind Atlas of Vojvodina, 2008).

Besides košava, there are other importanat winds in Vojvodina such as south, north and north-eastern wind.

Figure 1 presents the average annual wind speed in Vojvodina at $100 \mathrm{~m}$ above the ground. Knowing that the minimum average wind speed for economically viable operation of a wind turbine is between 5 and $6 \mathrm{~m} / \mathrm{s}$, depending on the type of wind turbines, clearly distinguishes the southern part of Banat as a region with favorable wind potential for the construction of wind farms.

The areas suitable for the construction of wind farms must have between 200 and $250 \mathrm{~W} / \mathrm{m}^{2}$ wind power density to achieve economically viable production of electricity. Figure 2 shows that southern part of Banat is identified as the area with highest values of mentioned indicators and therefore represents an suitable area for the construction of windmill farms.

After the aforementioned studies, further analysis were conducted on certain locations in Vojvodina. A number of measuring poles were placed in 2006 and 2007 with the aim to measure the speed, direction and other parameters of wind at specific locations.

There are other necessary technical conditions for the operation of windmill farm. Wind turbines which produce greater power must be connected to the transmission or distribution electrical network to supply consumers with electricity. Due to its relief, the area of AP Vojvodina has very good coverage of both the transmission and distribution network, therefore locations of windmill farms are not conditioned by this criteria.

Other technical conditions for the construction of wind turbines include adequate transportation infrastructure and the availability of land. In the area that has a technically exploitable wind potential these conditions are met or can be met by certain investments.

All negative impacts on the environment must be recognized when planning the location of windmill farms. Although the use of wind energy globally has a very positive impact on the environment, some of the negative effects occur at the local level. Some of these negative impacts are (Spatial and environmental aspects of renewable energy, 2009):

- Noise;

- Light reflection;

- The impact on flora and fauna;

- The visual impact.

The problem of noise, although perhaps the biggest problem, can easily be solved by building windmill farms at some distance from populated areas. This distance is usually a minimum of $1 \mathrm{~km}$, or for rarely populated areas 500m. These conditions are defined in the municipality spatial plans. 


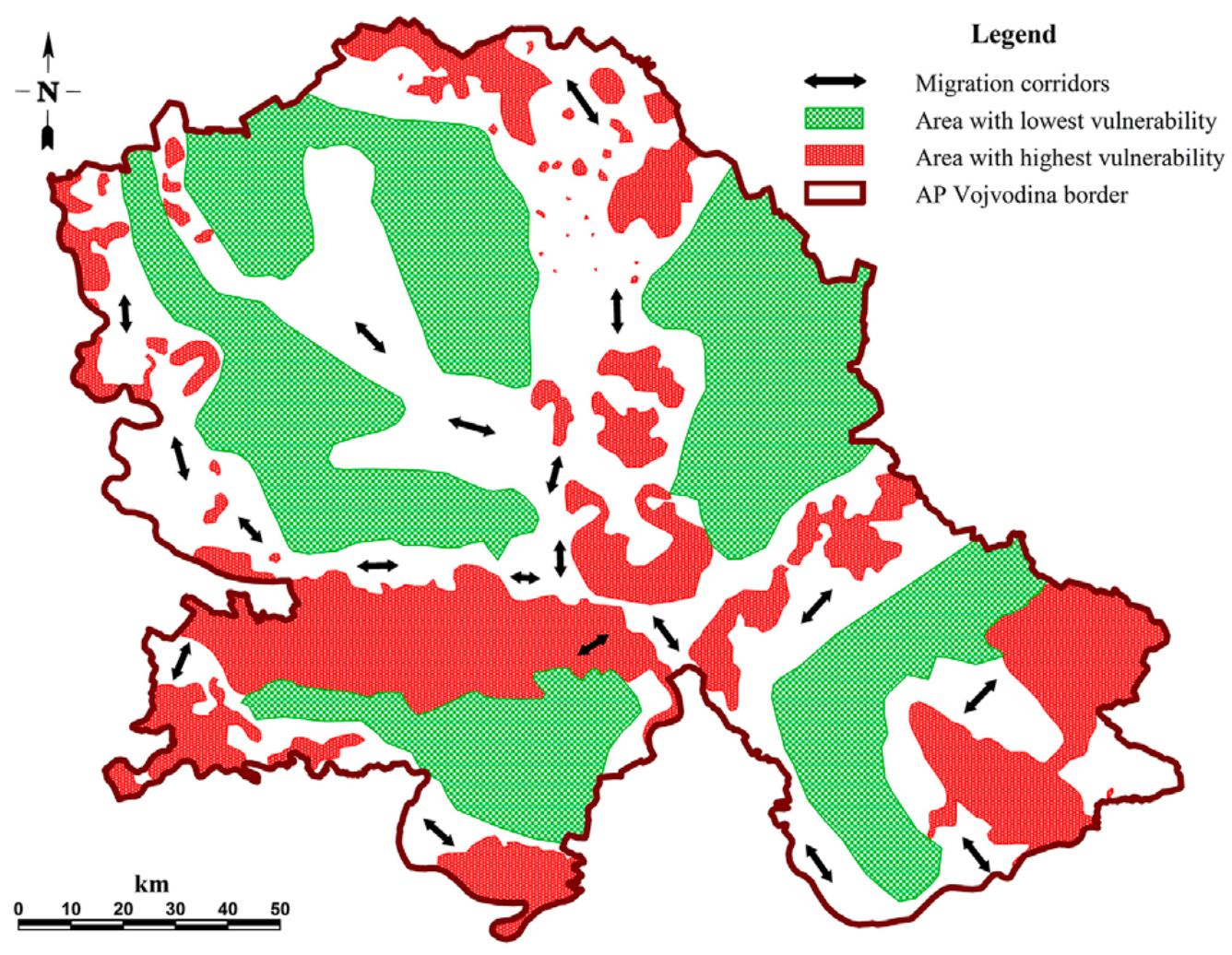

Figure 3. Vulnerability and migration corridors of birds (Establishment of ecological networks in AP Vojvodina, 2009)

Light reflection is almost overcome by technological advancement of wind turbines themselves. It is not a big problem for people, but it jeopardizes the local fauna. The biggest environmental problem for the construction of windmill farms in Vojvodina are birds and bats.
A document "Establishment of ecological networks in AP Vojvodina" (2009) contains a section "Windmill farms and preservation of biodiversity", which refers to the impact of windmill farms on birds.

Green markings on Figure 3 present areas with the lowest bird vulnerability. It is important to note that

Table 1. Planned windfarms in AP Vojvodina

\begin{tabular}{|l|l|l|l|l|l|}
\hline № & Windfarm (capacity) & Municipality & $\begin{array}{l}\text { Number of } \\
\text { turbines }\end{array}$ & Phase of development & $\begin{array}{l}\text { Expected beginning } \\
\text { of construction }\end{array}$ \\
\hline 1. & Alibunar (174 MW) & Alibunar & 58 & Local EIA assessment approve & 1 year \\
\hline 2. & $\begin{array}{l}\text { Alibunar (42 MW) } \\
\text { Malibunar (8MW) }\end{array}$ & Alibunar & $21+4$ & $\begin{array}{l}\text { Local ElA assessment approve / } \\
\text { Building permit acquired }\end{array}$ & 1 year \\
\hline 3. & Dolovo (Čibuk 1) (158MW) & Kovin & 57 & $\begin{array}{l}\text { Local EIA assessment approve / } \\
\text { Building permit acquired }\end{array}$ & 1 year \\
\hline 4. & Kovačica (125MW) & Kovačica & 39 & $\begin{array}{l}\text { Local ElA assessment approve / } \\
\text { Building permit acquired }\end{array}$ & 1 year \\
\hline 5. & Bela Anta (120MW) & Pančevo & 40 & $\begin{array}{l}\text { Early stage (preparation of urban } \\
\text { plan) }\end{array}$ & 5 years \\
\hline 6. & Plandište (102MW) & Plandište & 34 & Construction of substation & Started in 2013. \\
\hline 7. & $\begin{array}{l}\text { Čibuk 2 (ex Bavanište) } \\
\text { (160MW) }\end{array}$ & Kovin & $57(T B C)$ & Early stage & $3-5$ years \\
\hline 8. & Košava (120MW + 6MW) & Vršac & 41 & Local ElA assessment approve & $1-3$ years \\
\hline 9. & Inđija (20 MW) & Inđija & 10 & $\begin{array}{l}\text { Local ElA assessment approve / } \\
\text { Building permit acquired }\end{array}$ & $1-3$ years \\
\hline 10. & Banatska Topola (Bašaid) & Kikinda & & $\begin{array}{l}\text { Local EIA assessment approve / } \\
\text { Building permit acquired }\end{array}$ & 1 year \\
\hline
\end{tabular}




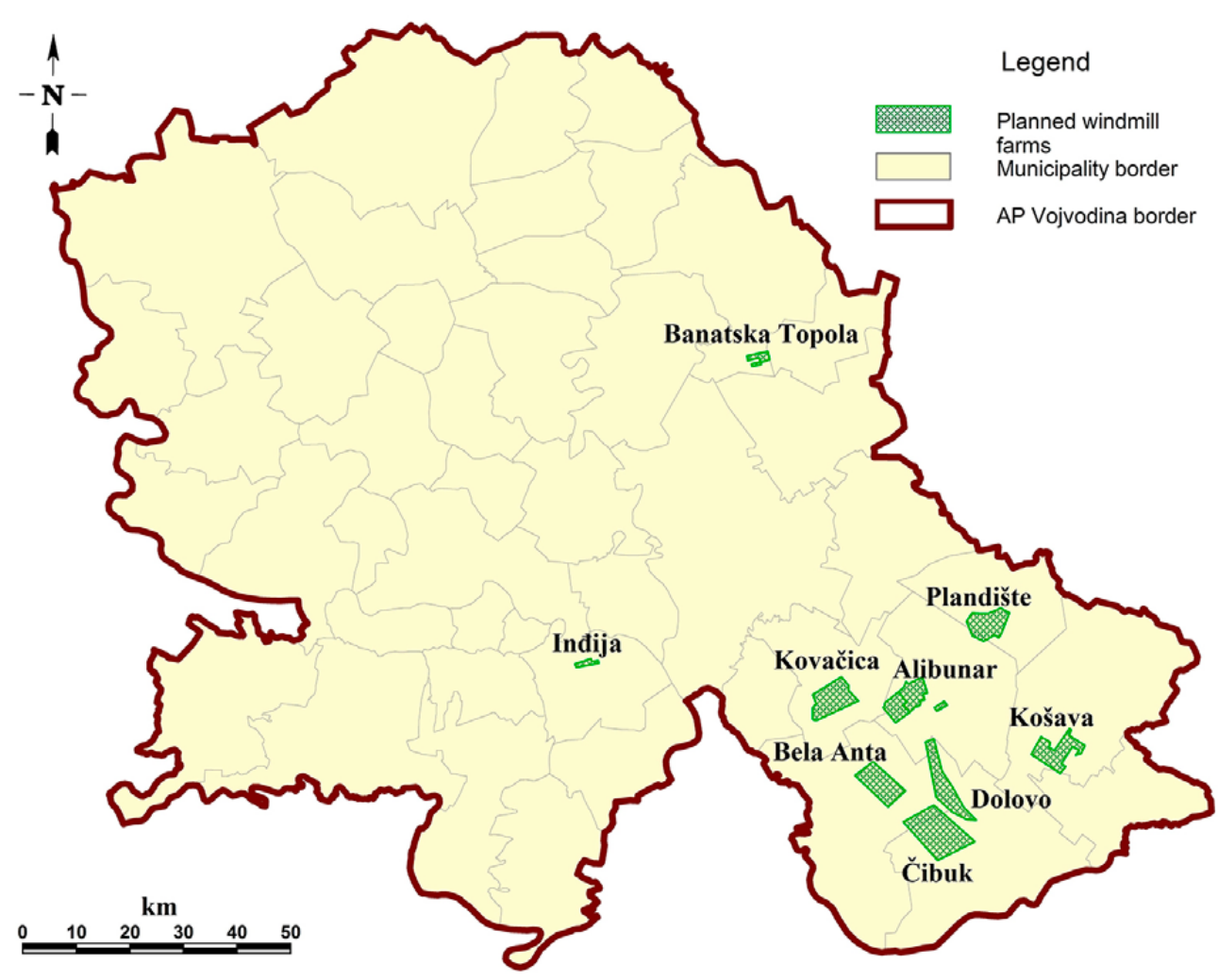

Figure 4. Planned windmill farms in AP Vojvodina (The cumulative impact assessment- Alibunar windmill park, 2015)

the red markings are all areas of high birds vulnerability and all areas protected by law in Vojvodina. Therefore it's obvious which locations are suitable for the construction of wind turbines in terms of environmental protection.

South Banat, which has the greatest wind potential is also the area of highest bird vulnerability. Although it's not legally prohibited to build windmill farms in areas with high bird vulnerability (in Serbia), investors do not want to invest in these locations because of possible conflicts. The laws of some EU countries prohibit the construction of windmill farms in these locations and thus such a provision can be expected on the territory of Vojvodina in the future.

Municipality spatial plans defined that for all planned wind farms in Vojvodina most detailed urban plans must be done before construction. So far, seven of such urban plans for the planned wind farms were done, and the two plans are in the preparatory phase. All of them are shown in Table 1 and their locations in Figure 4.

\section{Defining the most favorable locations for the construction of windmill farms in Vojvodina}

Taking into account all the elements needed to define the areas favorable for the construction of windmill farms, it is necessary to define criteria for the evaluation of the suitability of locations in Vojvodina for construction of such farms.

The method of evaluation for these locations consists of several steps:

- Defining the evaluation criteria;

- Determining the significance of certain criteria;

- Defining the evaluation of certain criteria;

- Set up a rating, final evaluation and ranking.

The criteria used to define favorable areas for the construction of windmill farms are:

- Wind speed $(>5 \mathrm{~m} / \mathrm{s})$;

- The density of wind power $\left(>200 \mathrm{~W} / \mathrm{m}^{2}\right)$;

- The frequency of occurrence and the predominant wind direction;

- Infrastructure equipment-proximity of high voltage transmission power grid;

- Protected areas (the existence of mechanisms to ban the building of power plants on these areas);

- Threatened birds and bats.

Considering the main goal of this paper, the main method to defane the most suitable location is a cartographic method. Maps from the Atlas of winds of AP Vojvodina, referral maps from the Regional Spatial Plan of AP Vojvodina, the map of vulnerability of birds and bats, as well as topographic maps of dif- 


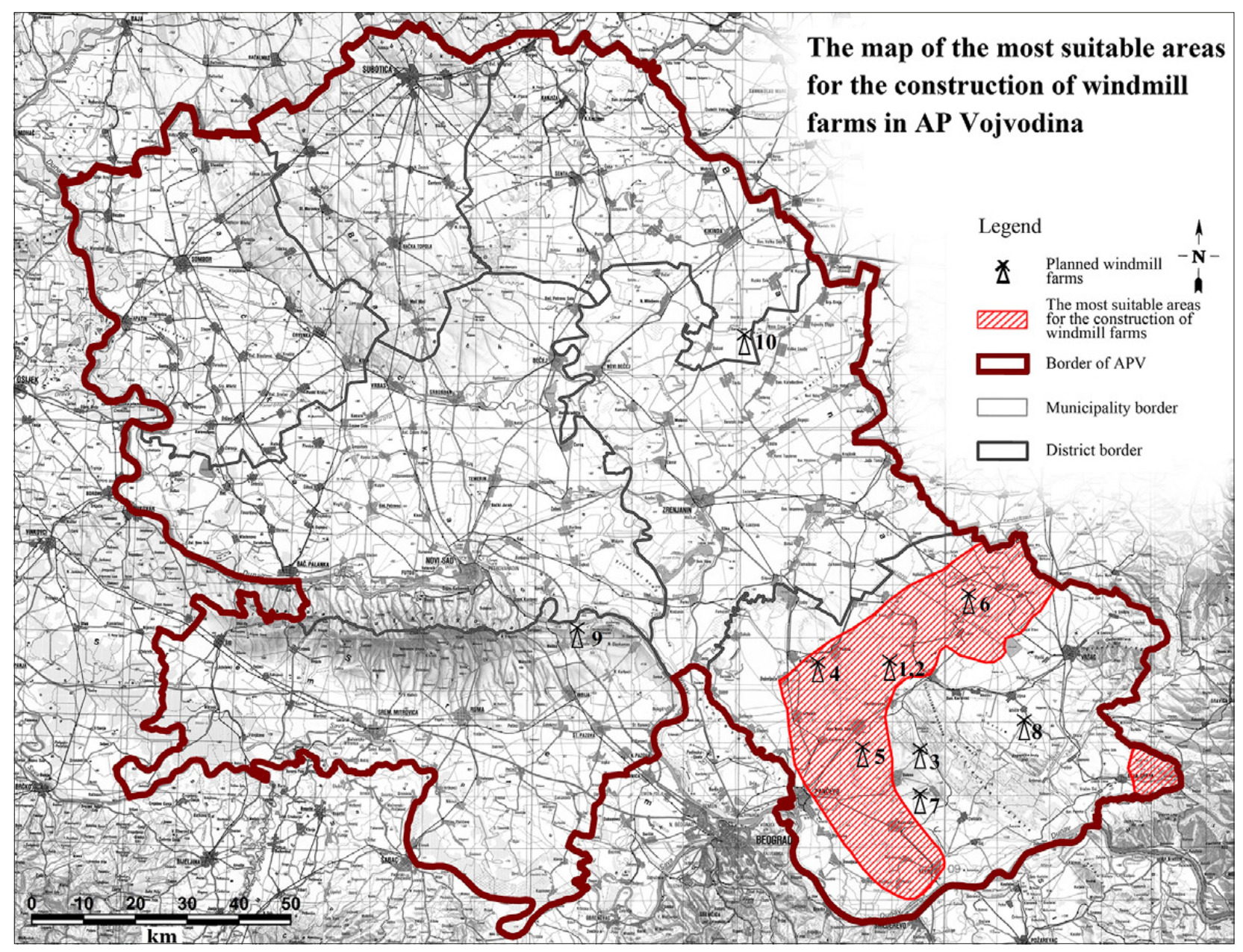

Figure 5. The most favorable areas for the construction of windmill farms in Vojvodina based on the location evaluation methods and criteria for defining the areas favorable for such construction

ferent scales were used as a starting point for creation of final map. The main problem while making final map was interpolation of various maps with different content, scale and method of generalization. The problem is overcome by using a geographic information system (GIS), by digitizing the required maps, defining the limit values of the indicators for the separation of the aforementioned locations and their presentation on the map with GeoMedia software.

As a result of the evaluation of these criteria, favorable locations for the construction of windmill farms in Vojvodina were defined shown in The map of the most favorable areas for the construction of windmill farms in Vojvodina (Figure 5). The numbers of planned windmill farms on this map correspond to the numbers of windmill farms in Table 1.

All areas favorable for the construction of windmill farms are located in southern Banat primarily due to the highest values of speed and power density of wind, as the most important criteria (Figure 5). Although the values of these two indicators have the highest values precisely in the area of Deliblato Sands (Deliblat- ska peščara), it is prohibited to build power plants in this area due to the status of a Special nature reserve. Except for the above, a criterion that perhaps conditioned the defined area the most is vulnerabilityt of birds and bats. It represents an obstacle to the construction of windmill farms in Vojvodina. Only areas with low vulnerability for birds and bats are defined as suitable for construction of windmill farms, due to the possibility of conflict if building in locations with middle or high birds and bats vulnerability. Construction of windmill farms in such location is forbidden in EU.

It is interesting that only four planned windmill farms are located in a defined area. Wind farm "Kula" in the Kula municipality, which began working in November 2015 as the first wind farm in Serbia, is outside the defined area. Wind speed on this location is below the average for the AP vovodina, which is overcome by the construction of the highest wind turbines $(178 \mathrm{~m})$ in Southeast Europe. The economic viability of such project is still too early to comment.

Wind farms that are located in close proximity to the defined area are encountered with the aforemen- 
tioned conflicts (birds and bats) which can come to suspension of windmill farms projects.

To determine the specific locations for the construction of windmill farms, specialized measurements of wind characteristics at several heights above the ground are necessary, as well as other meteorological measurements such as temperature, pressure and humidity. There are certain rules for setting up a measuring stations for wind, as well as for orientation of sensors on the measuring poll and for the collecting and recording data. Depending on the used sensors and data processing systems, measurement speed and wind direction is done within one or a few seconds. On the basis of these measurements, average values are calculated for each period of $10 \mathrm{~min}$ utes.

Specialized wind measuring have been completed at over 20 locations in Serbia using the measuring poles height of $40 \mathrm{~m}$ to $80 \mathrm{~m}$. The measurements confirm the significant wind energy potential, and studies done on the basis of these measurements that the projects are economically justified.

\section{Conclusion}

Vojvodina is a region of exceptional potential for the use of wind energy to generate electricity. The final results show that Vojvodina has high quality winds, especially at heights of over $50 \mathrm{~m}$ above the ground, especially over 10om above the ground, which corresponds to modern windmill power of 2-5 MW. Particularly noteworthy is the area of south and southeast Banat where the exploitation of wind energy is economically viable (average annual wind speeds over $6 \mathrm{~m} / \mathrm{s})$.

However, in Vojvodina there is a problem of conflict of interest between sustainable development in the energy sector by construction of windmill farms on the area of the greatest wind energy potential and insistence on prohibition of construction in this area (Special Nature Reserve). The biggest problem, even for the already planned windmill farms, present migration corridors of birds and bats in southern Banat. Some of the planned windmill farms are located precisely in these corridors, which can lead to the abolition of the projects construction.

New Energy Law significantly improves the situation when the renewable energy and thus wind energy is concerned. Each producer of electricity from renewable energy sources is in the category of privileged producer which opens the way to new possibilities in the development of wind energy. This approach made windmill farm economically viable, which attracted foreign investors to finance construction of windmill farms in Vojvodina.

\section{References}

Awerbuch, S. 2006. Wind Economics in 21st Century. New Energy - Magazine for Renewable energy 1, 44-47.

Baños, R., Manzano-Agugliaro, F., Montoya, F.G., Gil, C., Alcayde A., Gómez, J. 2011. Optimization methods applied to renewable and sustainable energy: A review. Renewable and Sustainable Energy Reviews 15, 1753-1766.

BDSP University of Stutgart. 2007. Wind energy. University of Stutgart, Stutgart.

Chen, H., Li, Z. 2009. Design optimization and site matching of direct-drive permanent magnet wind power generator systems. Renewable Energy 34, 1175-1184.

Dodić, S.N., Vučurović, G.D., Popov, D.S., Dodić, M.J., Zavago, Z.Z. 2010. Concept of cleaner production in Vojvodina. Renewable \& Sustainable Energy Reviews 14, 1629-1634.

Dukić, D. 1981. Climatology. Scientific book, Belgrade. (in Serbian)

Đurišić, Ž., Bubnjević, M., Mikičić, D., Rajaković, N. 2007. Wind Atlas of Serbian Region Vojvodina. Proc. of European Wind Energy Conference EWEC.

Electric Power Industry of Serbia (EPS) 2002. The possibility of using wind energy for electricity generation. (in Serbian)

Energy Balance of the Autonomous Province of Vojvodina for 2009 2008. Provincial Secretariat of Energy and Mineral Resources, Novi Sad. (in Serbian)

Energy Balance of the Autonomous Province of Vojvodina for 2010 2009. Provincial Secretariat of Energy and Mineral Resources, Novi Sad. (in Serbian)

Energy Balance of the Autonomous Province of Vojvodina for 2011 2010. Provincial Secretariat of Energy and Mineral Resources, Novi Sad. (in Serbian)

Establishment of ecological networks in AP Vojvodina 2009. Institute for nature conservation of Serbia, Belgrade. (in Serbian)

Gburčik, P., Gburčik, V, Gavrilov, M, Srdanović, V., Mastilović, S. 2006. Complementary Regimes of Solar and Wind Energy in Serbia. Geographica Pannonica 10, 22-25.

Golušin, M, Tešić, Z., Ostojić, A. 2010. The analysis of the renewable energy production sector in Serbia. Renewable \& Sustainable Energy Reviews 14, 14771483 .

Golušin, M., Munitlak-Ivanović, O. 2011. Kyoto Protocol implementation in Serbia as precognition of sustainable energetic and economic development. Energy Policy 39, 2800-2807.

Josimović, B., Pucar, M. 2010. The strategic environmental impact assessment of electric wind energy 
plants: Case study 'Bavanište' Serbia. Renewable Energy 35, 1509-1519.

Komarov, D., Stupar, S., Simonović, A., Stanojević, M. 2012. Prospects of wind energy sector development in Serbia with relevant regulatory framework overview. Renewable and Sustainable Energy Reviews 16, 2618-2630.

Lalić, D., Popovski, K., Gecevska, V., Popovska-Vasilevska, S., Tešić, Z. 2010. Analysis of the opportunities and challenges for renewable energy market in the Western Balkan countries. Renewable \& Sustainable Energy Reviews 15, 3187-3195.

Michlak, P., Zimny, J. 2011. Wind energy development in the world, Europe and Poland from 1995 to 2009; curent status and future perpectives. Renewable and Sustainable Energy Reviews 15, 2330-2341.

Micić, T., Lukić, T., Đorđević, J., Basarin, B., Bjelajac, D., Hrnjak, I., Marković, B. S., Sakulski, D., Đerčan, B., Bubalo-Živković, M., Pavić, D., Lazić, L. 2014.
Determination of Wind Energy Potential and its Implementation Concept for the Electricity Market in the Vojvodina Region (North Serbia) - An Overview. Geographica Pannonica 18-1, 6-17.

Spatial and environmental aspects of renewable energy 2009. Spatial Development Strategy of the Republic of Serbia - analytical basis. IAUS, Belgrade. (in Serbian)

Strategy of Energy Development in the Republic of Serbia by 2015 - for the period 2007- 2012 2005. Belgrade (in Serbian)

The cumulative impact assessment- Alibunar windmill park 2015. Wind Vision. Atkins, Novi Sad. (in Serbian)

Tükenmez, M., Demireli, E. 2012. Renewable energy policy in Turkey with the new legal regulations. Renewable Energy 39, 1-9.

Wind Atlas of Vojvodina 2008. Faculty of Technical Sciences, Novi Sad. (in Serbian) 